\title{
The Existence of Farming Types in Dryland Agriculture in Timor, Indonesia
}

\author{
Tony Basuki ${ }^{1 *}$, Debora Kana Hau ${ }^{1}$, Jacob Nulik ${ }^{1}$, Evert Y Hosang ${ }^{1}$, Bernard \\ deRosari $^{1}$, and Yohanis Ngongo ${ }^{1}$
}

${ }^{1}$ Assessment Institute of Agricultural Technology (AIAT) East Nusa Tenggara, Indonesia

*Corresponding author Email: tony.basuki84@gmail.com

\begin{abstract}
Timor Island is part of the East Nusa Tenggara province in Southeast Indonesia. This island is one of several large islands in East Nusa Tenggara which is climatologically included in the semi-arid area. The agroecological conditions have formed a specific dry climate dry land farming system. This study has been carried out to get an idea of the farming type within the scope of the farming system in Timor Island. This study used a survey method by collecting data and information on 370 farmers as respondents as randomly selected and assisted by a list of prepared questions. The data and information were covered the following aspects: (i). farmer characteristics; (ii). type of farming and orientation; (iv). commodity types and cropping pattern (v). planting patterns and cropping calendars, and (vi). farm management. Furthermore, all the data and information were tabulated and analyzed descriptively. It was concluded that most types of farming in East Nusa Tenggara are mixed farming, where this type of farming cultivates several commodities including livestock in one or several farming locations. This type of farming is part of an adaptation strategy to the agroecological environment in a semi-arid area by local farmers. At this stage, the farming orientation has shifted from previously being subsistence to a slight change towards commercial orientation. However, the farm performance was still classified as unproductive. This farming hasfaced with some challenges, namely the limited productive workforce, very simple cultivation management and not supported by cultivation technology/innovation, and the lack of available capital. There are no visible signs of an Integrated Farming System (IFS), even though IFS components are available for use.
\end{abstract}

Keywords: Integrated farming system, multi-commodity, mixed farming, semi-arid

\section{INTRODUCTION}

Timor Island of the province of East Nusa Tenggara (ENT) is located in Southeast Indonesia. This island is one of several large islands in East Nusa Tenggara, which is climatologically included in the category of semi-arid area. Semi-arid region is an area that has a relatively lower amount of rainfall compared to evaporation potential. Based on the amount of rainfall, the island of Timor belongs to $\mathrm{F}$ zone, where the amount of annual rainfall is $1500 \mathrm{~mm}$ with $3-4$ wet months and an average temperature of $26^{\circ} \mathrm{C}[1,2]$.

Based on the edaphic aspect, the soils in Timor are dominated by young soils with weak weathering development, such as Entisols and Inseptisols. Weathering of the underlying limestone is the main source contributed to the development of both the
Alfisols and Mollisols [3]. Both types of soil generally have a shallow solum of less than $20 \mathrm{~cm}$, thus limiting the growth and development of plant roots. The nature of this soil is closely related to the condition of the source rock of local soil formation, where geologically, the island of Timor is formed from typical tectonic processes such as forces and folds. These characteristics can be seen from the existing geological formations, such as the Bobonaro Formation, the Nule Formation, and others $[4,5,6,7]$.

It is noted that $85 \%$ of ENT household communities are farmers [8]. Thus, mostof the population of ENT are farmers whose farms are faced with the biophysical conditions mentioned above. Therefore, what farmers do to deal with regional biophysical conditions like this is an adaptation strategy in farming, namely the formation of specific types of local farming systems. This adaptation 
strategy is concerned with minimizing the risk for farmers [9].

The results of the identification of local farming systems, indicate that there are twoforms of farming that can be seen, namely the form of monoculture farming and the form of multi-commodity-based farming. The form of monoculture farming is farming decisions based on one commodity in one land, and conversely the form of multi-commodity farming is farming that involves several commodities including livestock in one or several farming locations. Among these two forms of farming, the form of multi-commodity farming is farming in the province of East Nusa Tenggara, especially on the island of Timor.

This paper describes the existence of types of farming on the island of Timor which include types of commodities, farming calendars, production processes and management, production orientation of several dominant types of farming. The description of each of these farms is obtained from the results of a farming survey conducted for several months in 2021 inalmost all districts on the island of Timor.
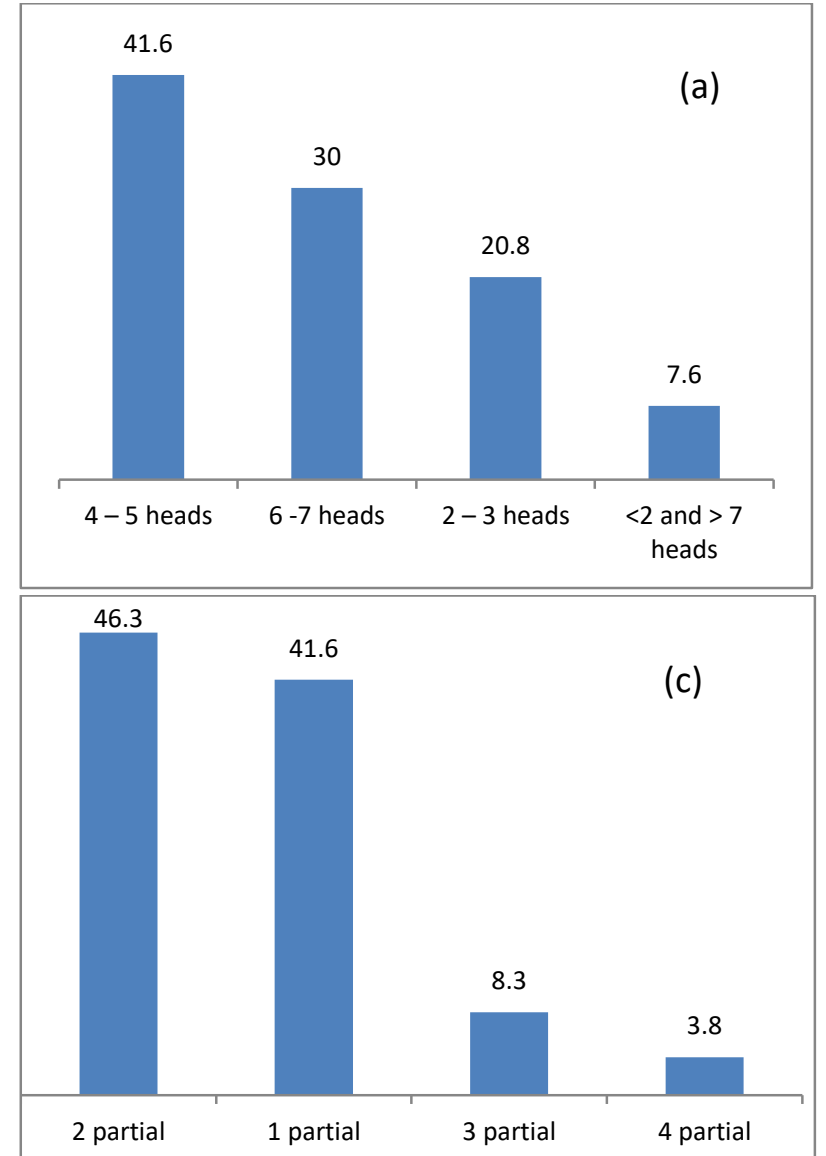

\section{MATERIALS AND METHODS}

This study was carried out using the survey method, within the scope of the farming system on Timor Island, and located in the districts of Kupang Regency, Kupang City, South Central of Timor, North Central of Timor, Belu, and Malaka. The data was collected through technical interviews assisted by a list of questions to randomly selected 370 farmers. The questions were related to the following aspects: (i). farmer characteristics; (ii). types of farming and orientation; (iii). commodity type and cropping pattern (iv). cropping patterns and cropping calendars, and (v). farm management. All of the data were tabulated and analyzed descriptively.

\section{RESULTS AND DISCUSSIONS}

\subsection{Farmers Characteristics}

The farmer characteristics related to their farming performance were the number of people per household, the number of productive workers, the number and area of land cultivated. The farmer characteristics were presented in Figure 1.

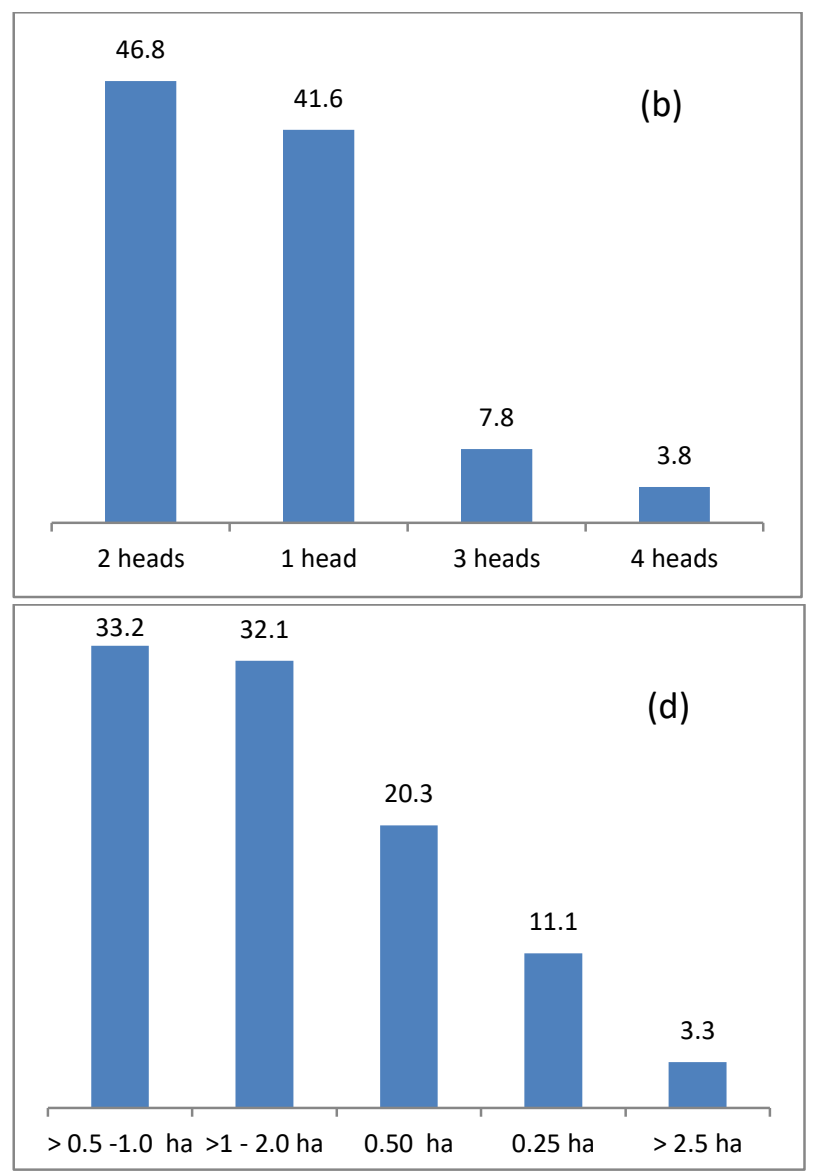

Figure 1. Percentage of the number of people per farmer household (a) and the percentage of the number of productive workers per farmer household (b), the amount of land cultivated by each farmer each season (c), and the area of land cultivated by each farmer each season (d) 
Table 1. Agricultural commodities in Timor Island

\begin{tabular}{|l|l|l|}
\hline Commodity Group & Commodity & Agroecosystems \\
\hline Food crops & $\begin{array}{l}\text { Corn, upland rice, cassava, sweet } \\
\text { potato, rice, bean, cowpea, pumpkin }\end{array}$ & $\begin{array}{l}\text { Ladang, rainfed rice fields } \\
\text { and irrigated rice fields }\end{array}$ \\
\hline Livestock & Cows, pigs, goats, chickens & Garden house, grazing field \\
\hline Vegetables crops & $\begin{array}{l}\text { Mustard greens, water spinach, eggplant, } \\
\text { tomatoes, chilies, longbeans, etc. }\end{array}$ & Garden house and ladang \\
\hline Fruit plant & mango, avocado, orange, banana & Garden house and ladang \\
\hline Plantation crops & cashew coconut & Garden house and ladang \\
\hline
\end{tabular}

Source: primary data from the survey

Table 2. Planting Patterns, Planting Time, Harvest Time in each agroecosystem on the Timor Island

\begin{tabular}{|l|l|l|l|}
\hline Agroecosystem & Planting Patterns & Planting Time & Harvest Time \\
\hline Ladang & FC - Fallows & November/December & March/April \\
\hline House garden & FC - Fallows & November/December & March/April \\
& FC - Vegetables & May /June & June to November \\
\hline Irrigated rice & Rice - Rice & January/February \& & May /June \& \\
& Rice - Fallows & June/July January/February & May/Juni \\
\hline Upland rice & Rice - Fallows & January/February & May /Juni \\
\hline Livestock & - & All the time & All the time \\
\hline Mamar & - & All the time & All the time \\
\hline
\end{tabular}

FC: Food crops: corn, rice, sorghum, beans

Figure 1 was showed that Timorese farmers have cultivated with the area, and the number of locations varied land. A total of $41 \%$ of farmers were cultivated in one location, and $46.3 \%$ had two locations. The total arable area was focused on four range categories, namely $33.2 \%$ of farmers have an arable land area of $>0.5-1.0$ ha, followed by $32.1 \%$ with an arable area of $>1-2.0$ ha. Meanwhile, the farmers with 0.5 ha of an arable area were $20.3 \%$

The availability of productive workers for each farmer household was showed that $46.8 \%$ of households have two workers and $41 \%$ of households only have one worker. The number of people per household showed that 4 to 5 people dominated $41.6 \%, 6$ to 7 people occupied $30 \%$ of households, and $20.8 \%$ were settled by 2 to 3 people. The existing condition of farmer characteristics in Figure 1 was indicated that the farming management was experiencing significant challenges with the available productive workers. The 1.0 ha of the arable area was burdened and cultivated by one productive worker per household. This condition has consequences for the quality of farming management.

\subsection{Agroecosystems, Commodities and Cropping Patterns}

There are six main agroecosystems for farming environments in Timor Island. These six agroecosystems were ladang, house garden, rainfed rice fields, irrigated rice fields, grazing fields, and mamar. Each of these agroecosystems was characterized by its main commodity. The main commodities mainly were used for food purposes or selling to the market. As previously mentioned, the farming types were dominated by mixed farming with more than three types of commodities, including livestock. The results were showed that $100 \%$ of farmers have more than three types of commodities. A list of agricultural commodities in Timor Island was presented in Table 1.

The main factor in determining the success of farming in all agroecosystems was the availability of water. The results showed that $70 \%$ of water sources depend on rainfall, $13 \%$ on wells, and $7 \%$ on irrigation and other sources. Therefore, $66.5 \%$ of farmers often experience rain disturbances in the production process, $10 \%$ of farmers have a limited workforce, and $12.4 \%$ have low cultivation knowledge. 
A majority of $92.3 \%$ of farmers were cultivated corn as the main crop, and the rest was upland rice, especially in the sloping land (71.4\%). Besides, the other crops were cassava, pumpkin, and beans. These commodities were mix-cropped with corn $(61.3 \%)$, followed by cassavacorn $(13.3 \%)$ and beans-corn $(11.1 \%)$. The commodities planted with corn on the same land and the season were included in the cropping pattern as mixed cropping.

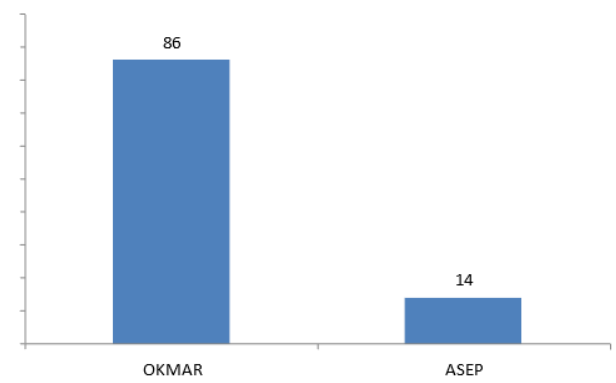

Figure 2. Percentage of farmers who planted during the OKMAR and ASEP planting periods in Timor Island

\subsection{Cropping Pattern, Planting Calendar and Livestock Keeping}

The cropping pattern and planting calendar in Timor Island generally was followed the rainfall pattern. Therefore, the cropping pattern and planting season in dry land was carried out during the rainy season (November/December - March/April). Outside the rainy season, the soil was left open without any plants. Meanwhile, on the paddy fields with sufficient irrigation capacity, a rice-paddy cropping pattern will also be possible. The first rice planting season was usually between January/February, and the harvest in April/May. The second rice planting season was started in June/July and finished in October/November. A summary of cropping patterns by agroecosystem in Timor Island was presented in Table 2. The planting calendar for the six agroecosystems was presented in Figure 2.

Table 2 showed that Timor Island has two planting periods: the October - March period (OKMAR) and the April - September period (ASEP). The Okmar planting period was the planting season carried out by most farmers with the rainfall water source. The Okmar period was in line with the rainy season in the region.
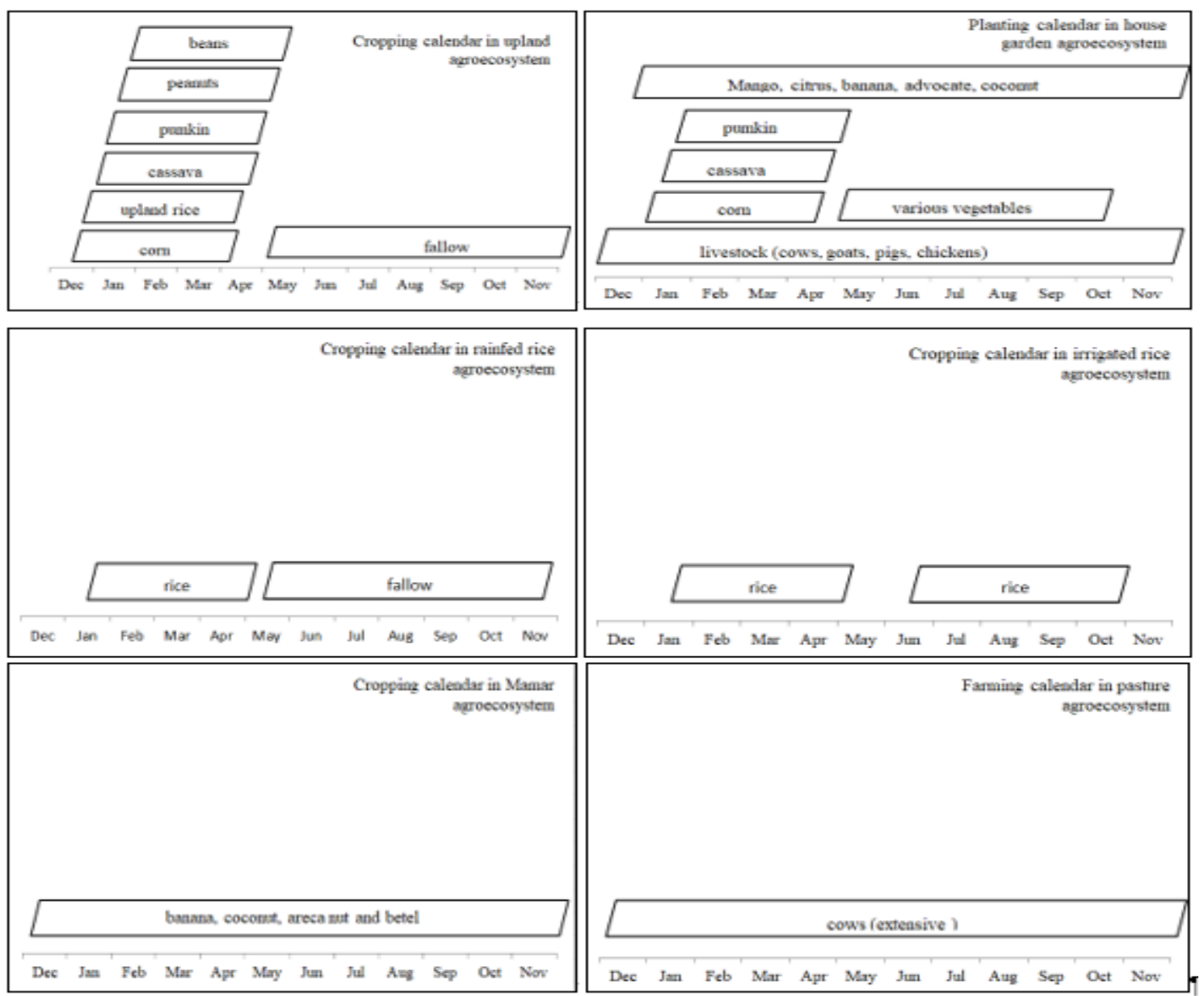

Figure 3. Cropping calendar for six agro-ecosyste $\mathrm{ms}$ in Timor 


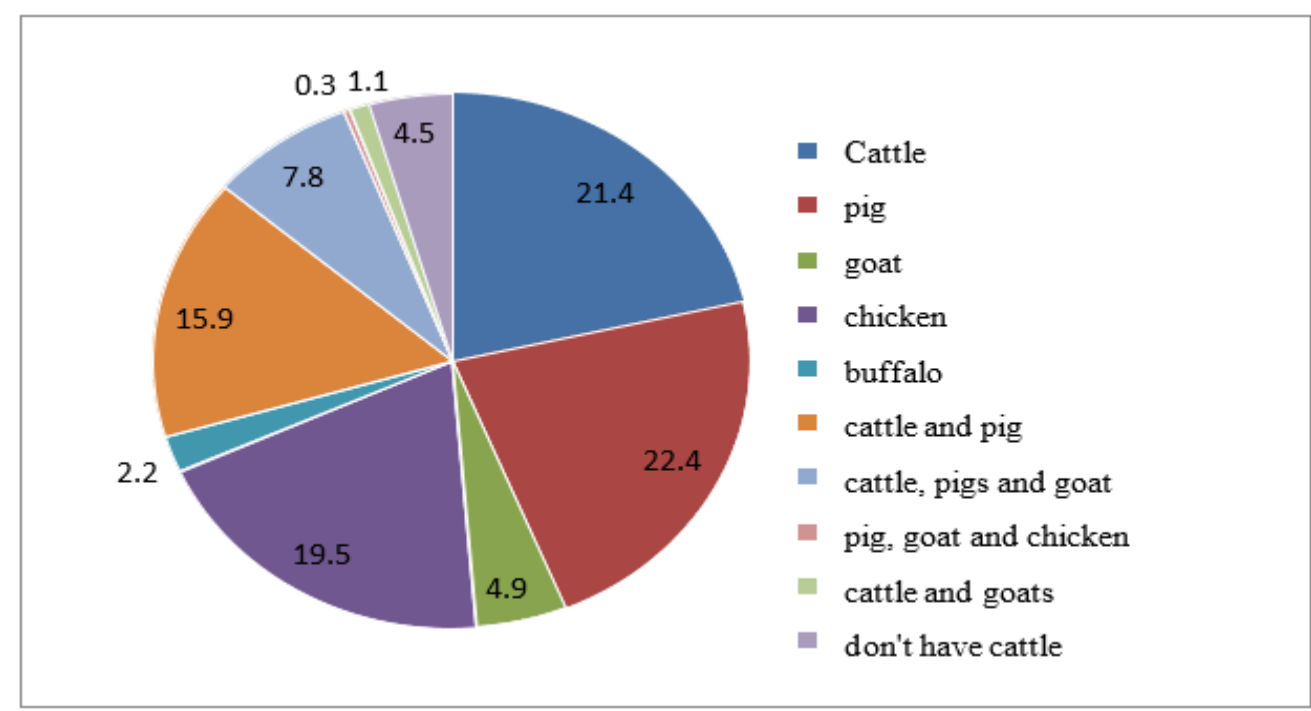

Figure 4. Percentage of farmers who raise livestock by type of livestock

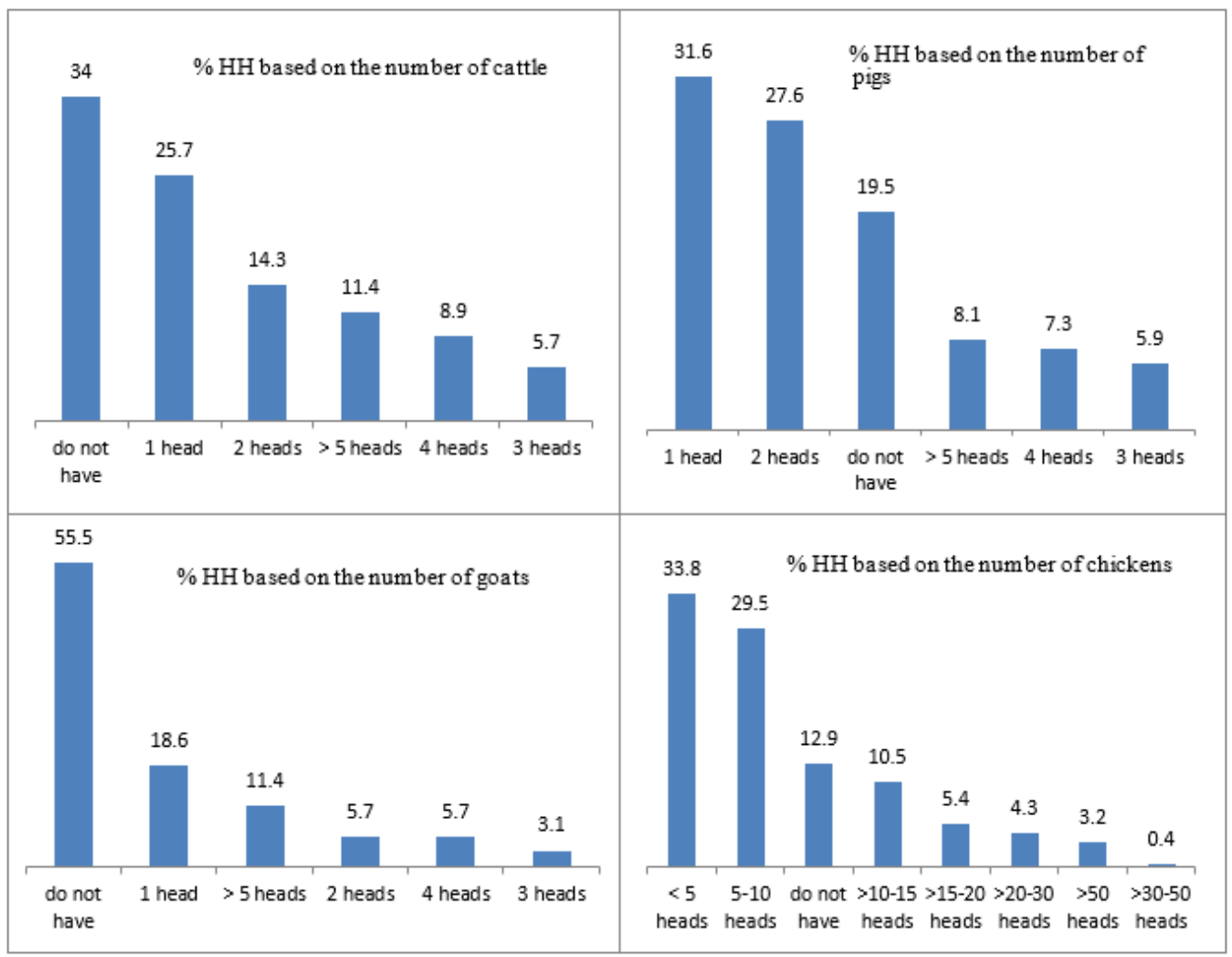

Figure 5. \% HH based on the number of cattle, pigs, goat and chickens owned

Furthermore, the ASEP planting period was called the off-season period.

Figure 3 was shown that the ladang and house garden agroecosystem was more complex than the other due to accommodating all commodities, such as food crops and livestock. The difference between the two agroecosystems is the production season. Ladang agroecosystem has a production season from midDecember to April, while the house garden has a yearround. The results showed that almost all farmers have a ladang as a center for food production and have farming activities in the house garden. The ouse garden was also accommodated the livestock business. Almost all farmers have owned livestock in the mixed farm, and only $4.5 \%$ of farmers do not own livestock.

Figure 4 was shown that the dominant livestock types owned by Timorese farmers were cattle, pigs, chickens, and goats. Figure 5 was revealed that the livestock ownership was low. Even the percentage of farmers who 
did not own cattle, pigs, goats, and chickens was higher, namely $34 \%, 19.5 \%, 55.5 \%$, and $12.9 \%$, respectively.

\subsection{Type of Farm and Orientation}

There are two types of farming in Timor Island: farming based on one commodity (monoculture) in one land and one season, and farming based on more than one commodity is not only one land and one season or referred to as mixed farming. two months were considered as the planting time that could not replace. Therefore, land preparation activities such as clearing new land, clearing, tillage, and constructing garden boundary fences are usually completed in October.

Farmers rarely used external inputs such as fertilizers (except rice), insecticides, and growth hormones during the production process. Farmers only carry out manual activities such as weed control, especially in corn or

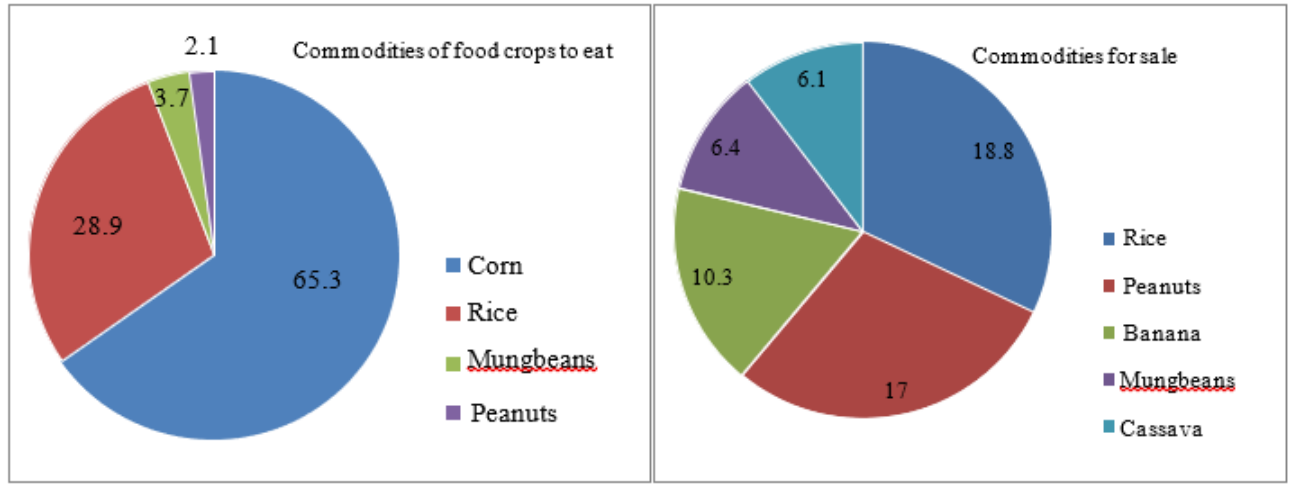

Figure 6. Commodities of food crops to eat and commodities for sale

Monoculture farming was generally carried out by business-oriented (commercial) farmers with one commodity base following the market demand. Examples of monoculture farming were lowland rice farming, corn farming, or vegetable farming. This farming type was produced according to the market demand and applied by the farmers with the access and market networks or farmers whose locations near the city or market. On the other hand, mixed farming was a type of farming that involved several agricultural commodities grown in one area or several fields, including livestock commodities. The orientation of this farming type has shifted from previously subsistence or solely for the fulfillment of family food to the food crops for sale (figure 6).

\subsection{Farm Management and Cultivation Process in Mixed Farming}

Farming management in Timor was relatively simple. This level of management was closely related to the capacity of available land resources, limited productive labor, equipment, and capital, as well as the orientation of farming which still tends to be subsistence. Therefore, only a few farming activities that can be reached, such as the timing of planting, land preparation, and seed preparation. This activity has no consequences for expenses (costs).

The reference for planting time used the experience of previous planting seasons in most of East Nusa Tenggara. The planting time for food crops (corn and beans) falls between November and December. These beans farming. Following the access to information development, few corn farmers have started using pre- or post-growth herbicides to weed control.

The livestock management was also quite simple. The livestock was released and free-grazed or housed in pens. The farmers did not need to prepare feed (such as grasses from native pastures) for released and free-grazed livestock. In contrast, the feed was taken (cut and carry) from around the field for housed livestock. The types of forage were Kabesak (Acacia leucophloea), Beringin (Ficus Sp), Gamal (Gliricidia sepium), Lamtoro (Leucaena leucocephala), Turi (Sesbania grandiflora), and others. Especially for pigs, the feed was household waste or concentrate feed purchased from the shop.

This simple farming management has consequences for small business scale, productivity, and production. For example, corn productivity was less than 2 tons/ha, with an average arable area was 0.25 ha, would be produced 0.5 tons/household/season. Another example is the low productivity of upland rice, 1.2 tons/ha, so the product obtained was $0.3 /$ household/season. Likewise, the productivity and production of other crops were low, such as cassava, peanuts, or green beans. In livestock farming, simple management was impacted on the low cattle productivity. For example, male Bali cattle grazed in the native pasture was needed a longer time (4-5 years) to reach market weight $(250-300 \mathrm{~kg})$, while with highquality (cut and carry) forage could shorten two years to reach market weight $[10,11]$

Ideally, a multi-commodity farming system has the opportunity to develop an integrated farming system 
(IFS). The IFS is a way of farming that manages various agricultural commodities simultaneously and supports each other. This farming system aims to make efficient use of resources (land, capital, labor) to produce food, feed, fertilizer. Several of the advantages of IFS are minimizing input from outside the system, minimizing business failure, maximizing business outputs, and diversifying sources of business income [12,13,14].

\section{CONCLUSION}

Farming types in ENT are closely related to the biophysical characteristics of the region which are dominated semi-arid and marginal ecosystems. Within this environment, farmers develop farming strategies to minimise risk and maintain a level of crop production for subsistence. Mixed farming practices have considered as the most common practice in ENT which are closely related to the limited productive labour, lack of capital and almost no external inputs used. Meanwhile, small number of farmers were started to embrace monoculture practice for commercial crops. Livestock is an integral important part of farming system in ENT, livestock provides main sources of animal protein for household and main source of income. A multi-commodity farming system has the opportunity to develop an integrated farming system (IFS).

\section{AUTHORS' CONTRIBUTIONS}

TB and EH contributed to data collection, data analysis and writing related to farming systems. JN and DKH contributed on paper proof reading discusion some aspect on livestock in dryland farming system. BdR and YN contributed to the data analysis and discussion related to socio-economic aspects.

\section{REFERENCES}

[1] Basuki T, B. deRosari, Syamsuddin, E.Y. Hosang, Y. Ngongo, J. Nulik, Y. Tay, M.S. Abolla, Y. Suek, H.Z. Kotta, L.S. Mboeik, U.G. Lio, E. Lerik. R. Ongo, A. B. Riw, S. Kefi, S. Pekudjawang, D. Suhadi, B. Permana, Grand design pembangunan pertanian lahan kering kepulauan Nusa Tenggara Timur. Buku. Dinas Pertanian Provinsi Nusa Tenggara Timur dan Balai Pengkajian Teknologi Pertanian Nusa Tenggara Timur, 2018.

[2] Basuki T, J. Nulik. Peta agroecological zone (AEZ) skala tinjau mendalam untuk provinsi Nusa Tenggara Timur (edisi kedua). Badan Penelitian dan Pengembangan Pertanian. Balai Pengkajian Teknologi Pertanian Nusa Tenggara Timur, 2007.

[3] Mella, W, A.R. Mermut, Genesis and mineralogy of soils formed on uplifted coral reef in West Timor, Indonesia. Geoderma, 154 (3-4), 2010, pp. 544-553.
[4] Basuki T, Y. Ngongo, Syamsuddin, in Ariningsih E. and E. Suryani (Eds) Understanding biophysical of bobonaro scaly clay soils of Timor for sustainable dryland farming improvement. Proceedings of International Workshop on Agricultural Risk and Dryland Development for Poverty Alleviation. IAARD Press, 2018.

[5] Audley-Charles, M.G, Tectonic post-collison procesesses in Timor. Geology, 2011, DOI: 10.1144/SP355.12.

[6] Audley-Carles, M. G, The Sumba Fracture: A major discontinuity between Eastern and Western Indonesia. Tectonophysics, 26, 1974, pp. 213-228.

[7] Martinez Duran, P, P. Baillie, E. Carrillo, G. Duval,. Geological development of the timor orogen. Geological Society of London, 490, 2020, pp. 329-490.

[8] BPS-NTT, Provinsi Nusa Tenggara Timur Dalam Angka (Nusa Tenggara Timur in Figures) 2020. 2020 .

[9] Ngongo, Y, Irawan, U. Haryati, Conservation agriculture in semi-arid area of Indonesia: lesson learnt to increase maize production and farmers' awareness on environmental friendly land management. IOP Conf. Ser: Earth Environ. Sci., 648, 2021

[10] Nulik, J, N. Dalgliesh, K. Cox, S. Gabb, Integrating herbaceous legumes into crop and livestock systems in eastern Indonesia. Canberra: ACIAR. 2013.

[11] Nulik, J, D. Kana Hau, Daily Body Weight Gain of Bali Cattle Fed with Leucaena Leucocephala as the Main Ration in West Timor, East Nusa Tenggara, Indonesia. Proceeding of The 6th International Seminar on Tropical Animal Production Integrated Approach in Developing Sustainable Tropical Animal Production, Yogyakarta, Indonesia - October 20-22, 2015, 2015.

[12] Hosang. E. Y, Syamsuddin, M. Pabendon, M. Sutherland, Genetic Variability in West Timor Landrace Maize Populations, 2019

[13] Kapa, M. J, N. R. E. Kotta, Y. Ngongo, Swidden Agriculture, food security and environment in semiarid area of Timor - Indonesia Proceeding of the International Conference on Agriculture, Environment and Food Security:2020, 2021.

[14] Suek. J, Irham, S. Hartono, L. R. Waluyati, Production risks of mamar, a traditional agroforestry system in Timor Island, East Nusa Tenggara Province, Indonesia. Asian Journal of Agriculture and Biology, 6(4), 2018, pp. 434-441. 